\title{
Identifying the decadal forest fire effects on conversion of forest cover to grassland in Bandipur Tiger Reserve through geospatial technology.
}

\author{
Ashwatha K. N.*, Tejaswini J. S.**, Dr. A. S. Rayamane**** \\ * Research Scholar, Dept. of Geography \& Geoinformatics, Bangalore University, Bengaluru - 560056. \\ ${ }^{* * *}$ Research Team Member, Wildlife Conservation Group, Adavi Field Station, Ragihalli Post, Bengaluru - 560083. \\ *** Research Guide, Dept. of Geography \& Geoinformatics, Bangalore University Bengaluru - 560056.
}

DOI: 10.29322/IJSRP.11.09.2021.p11702

http://dx.doi.org/10.29322/IJSRP.11.09.2021.p11702

\begin{abstract}
Bandipur Tiger Reserve is one of the first wildlife reserves in India to adopt Project Tiger in 1974. It is known worldwide for its magnificent faunal species. This Park is located in the Indian state of Karnataka, The Park spans an area of 913.04 square kilometers. The Park is part of the Nilgiri Biosphere Reserve and is famous for its significant tiger and elephant population along with sandalwood trees. Karnataka has the second highest tiger population in India also protecting several species of India's endangered wildlife. During recent years, this park has had incidents of repeated fires. During 2019, this park has witnessed massive forest fires which resulted in huge loss of vegetation and life forms. This research paper aims to identify the fire prone areas by integrating vegetation type, past history of forest fire occurrence, road network and human activity. The temporal satellite data from 2009 to 2019 have been analyzed to map the Forest fire areas using Geographical Information System (GIS) and Remote Sensing (RS) techniques. The areas of the forest which were most prone to fire in these ten years are identified by analyzing the causes for fire incidents in the park.
\end{abstract}

Index Terms- Forest fire risk zones, Geographic Information Science, Landuse and land cover, Remote Sensing.

\section{INTRODUCTION}

Bandipur Forest is a national park located in the Chamarajanagar district of Karnataka. This is attached to Mudumalai National Park of Tamilnadu on one side and Wayanad Wildlife Sanctuary of Kerala on the other [1]. This national park was preserved as "Venugopala Wildlife Sanctuary", with an area of 90 sq. km by the Maharaja of Mysore in 1931[2]. Later in 1985, this area was extended to 874.20 sq. km and named it as "National Park of Bandipur", according to the notification dated 19th February 1941. The sanctuary is well known for a variety of mammals like tigers, elephants and leopards. Due to the prominent number of tigers in the area, the site was set up as "Tiger Reserve" under Project Tiger 1974 by the Ministry of Environment and Forests, Govt. of India[3]. Subsequently, some of the adjacent forest areas of this national park merged into it and expanded to $880.02 \mathrm{sq}$. km. At present Bandipur Tiger Reserve spans about 913.04 sq. km encompassing the plantations which come under Karnataka State Forest Development Corporation (KFDC) in the year 2007-08 and Nugu Wildlife Sanctuary in the year 2010-11 together spanning a total area of $39.80 \mathrm{sq} . \mathrm{km}[4]$.

In forests like Bandipur Tiger Reserve, evergreen and semi-evergreen, dry deciduous, shrub and grassland types of vegetation can be seen. Over a long period of time, changes in the vegetation can be observed. It can be either natural or anthropogenic. Even if it does not change naturally, it can be forced to change by man-made disasters in Bandipur Tiger Reserve. The most important reason for this change is forest fire. Fire that happens naturally in the forest has an impact on plant communities. Although it plays an important role in maintaining the health of some ecosystems, it causes havoc for wildlife and fire smoke significantly reduces photosynthesis. Frequent fires can lead to forest degradation, even though it plays an important role in changing vegetation in the forest[5].

The grass, shrubs, creepers, herbs and small trees in the lower reaches of the forest can be destroyed by the fire. In some cases, the impact can be high, as it can reduce large trees into ashes. The fire on the ground destroys organic matter such as dry leaf, dry wood and grass which are necessary to maintain the maximum level of humus in the soil. This can also lead to soil erosion[6]. In this study, it can be seen that the forest fires last for a prolonged period of time which is the root cause for loss of vegetation. The process in which forests are transformed into grasslands[7].

Main objective of this study is to demarcate the boundaries of the Bandipur Tiger Reserve and its wildlife zones. To identify 10 years of the fire prone areas by integrating vegetation type. To study, currently what kind of changes are occurring in that forest area and analyzing Landuse and Landcover Change (LU\&LCC) about Spatio-temporal conditions. 


\section{MATERIALS AND METHODOLOGY}

\section{A. Study Area}

The Bandipur Tiger Reserve covers the Mysore and Chamarajanagar districts of Karnataka, India. The study area lies between the latitude $11^{\circ} .35^{\prime} .34^{\prime} ' \mathrm{~N}$ and $11^{0} .55^{\prime} .02^{\prime} ' \mathrm{~N}$ and between the longitude $76^{0} .12^{\prime} .17^{\prime \prime} \mathrm{E}$ and $76^{0} .51^{\prime} .32^{\prime}{ }^{\prime} \mathrm{E}$. Bandipur Tiger Reserve is divided into eleven wildlife ranges and their area is listed in Table 1. [8].

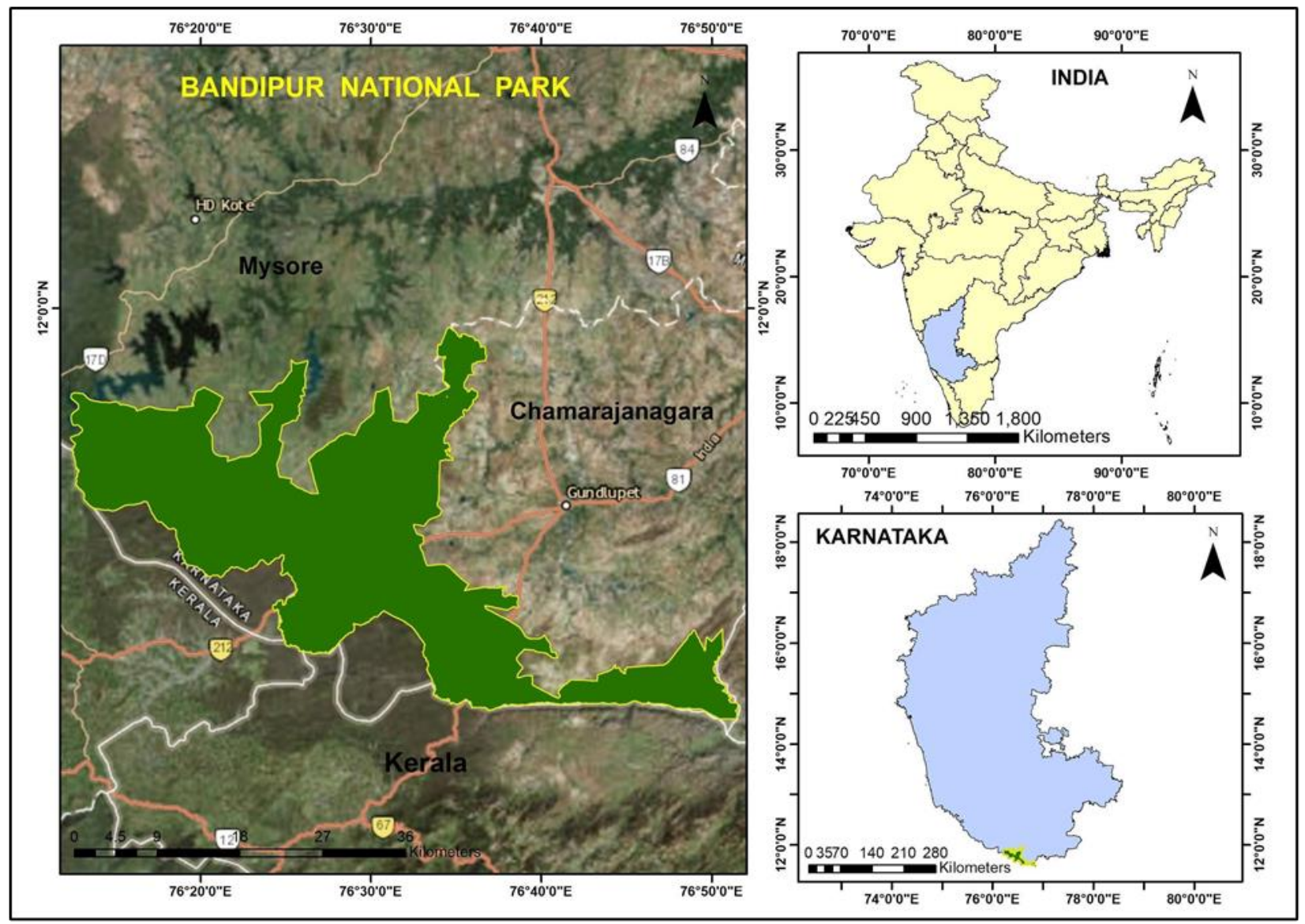

Figure 1. Location map of Bandipur Tiger Reserve

Table 1. Following table indicating the wildlife ranges of Bandipur Tiger Reserve and their respective areas.

\begin{tabular}{clr}
\hline Sl.No. & \multicolumn{1}{c}{ Wildlife Ranges } & Area $\left(\mathbf{k m}^{\mathbf{2}}\right)$ \\
\hline 1 & Gundre & 63.873878 \\
2 & N.Begur & 61.429479 \\
3 & Moliyar & 86.465078 \\
4 & Ainar Marigudi & 104.612217 \\
5 & Moalehole & 99.30222 \\
6 & Hediyala & 70.121588 \\
7 & Omkar & 83.695991 \\
8 & Maddur & 112.975731 \\
9 & Gopalaswamy Betta & 81.873496 \\
10 & Bandipur & 57.20395 \\
11 & Kundakere & 91.463377 \\
\hline
\end{tabular}




\section{B. Climate of the study area}

The Bandipur Tiger Reserve area has a dry subtropical climatic regime with distinct dry (March to June), wet (Middle of June to September) and cold (November to mid-February) seasons. It is quite hot and dry in summer, receiving heavy showers from the southwest monsoon and lighter rains from the north-east monsoon. The coldest months are December and January and hottest months are March and April. The temperature of the Bandipur Tiger Reserve is generally moderate, with a mean annual temperature of $24.16^{\circ} \mathrm{C}$ and maximum temperature of $29.66^{\circ} \mathrm{C}$, rarely going beyond $30^{\circ} \mathrm{C}$ and minimum temperature is $18.66^{\circ} \mathrm{C}$. The average annual rainfall ranges from $1270 \mathrm{~mm}$ Kalkere to $914 \mathrm{~mm}$ Bandipur. Storms and cyclones are very rare and there is no record of damage caused by them. The altitude varies from 780m Varanchi Stream to 1454.5m Gopalaswami betta above Mean Sea Level[9].

\section{Methodology}

The present study was based on ten sets of Remote Sensing data, Survey of India maps. These data were analyzed and forest fire areas have been mapped using Remote Sensing and Geographic Information System (GIS) Technologies - LANDSAT_5 (The Thematic Mapper sensor), LANDSAT_7 (The Enhanced Thematic Mapper (ETM+) sensor), LANDSAT_8 (Operational Land Imager_Thermal Infrared Sensor) and other materials used are Land Use and Land Cover changes. The details of the data used are given in Table-2. Primary data collected from Bandipur Tiger Reserve Buffer Zone Villagers and Karnataka Forest Department. Toposheets collected from the Geological Survey of India in 1:50,000 Scale. Landsat satellite images collected from USGS website.

The following methodology was used for land use and land cover change detection over the specified years 2010 and 2019 . First, LANDSAT-5 the Multispectral Scanner (MSS) and the Thematic Mapper (TM) instruments, Landsat-7 the Enhanced Thematic Mapper (ETM+) sensor and Operational Land Imager Thermal Infrared Sensor (OLI TIRS) images. (With Path/Row 144/052) acquired from 08 February 2010 to 13 March 2019 respectively. Refer table 2 for a description of the dates used in the study. The image resolution was 30 meters for pixel, land use and land cover classification were carried out by using the supervised classification following maximum likelihood method, using ArcGIS 10.1 software. The land use and land cover classes classified for the study are evergreen forest, semi evergreen forest, deciduous forest, Scrub/Grasslands and Water bodies[10-11]. Figure 2 illustrates the overall methodology used in the research.

Table 2: Information of the satellite images used for the preparation of land use and land cover change maps.

\begin{tabular}{cllllll}
\hline SI.No. & Data Type & Date of acquisition & $\begin{array}{l}\text { Path- } \\
\text { Row }\end{array}$ & $\begin{array}{l}\text { Resolution } \\
(\mathbf{m})\end{array}$ & Number of bands & Source \\
\hline 1 & LANDSAT_7 (ETM+) & $08-02-2010$ & $144 / 052$ & 30 & 8 & USGS \\
2 & LANDSAT_5 (MSS_TM) & $19-02-2011$ & $144 / 052$ & 30 & 7 & USGS \\
3 & LANDSAT_7 (ETM+) & $01-03-2012$ & $144 / 052$ & 30 & 8 & USGS \\
4 & LANDSAT_7 (ETM+) & $31-01-2013$ & $144 / 052$ & 30 & 8 & USGS \\
5 & LANDSAT_8 (OLI_TIRS) & $31-03-2014$ & $144 / 052$ & 30 & 11 & USGS \\
6 & LANDSAT_8 (OLI_TIRS) & $18-03-2015$ & $144 / 052$ & 30 & 11 & USGS \\
7 & LANDSAT_8 (OLI_TIRS) & $20-03-2016$ & $144 / 052$ & 30 & 11 & USGS \\
8 & LANDSAT_8 (OLI_TIRS) & $08-04-2017$ & $144 / 052$ & 30 & 11 & USGS \\
9 & LANDSAT_8 (OLI_TIRS) & $10-03-2018$ & $144 / 052$ & 30 & 11 & USGS \\
10 & LANDSAT_8 (OLI_TIRS) & $13-03-2019$ & $144 / 052$ & 30 & 11 & USGS \\
\hline
\end{tabular}

ETM: Enhanced Thematic Mapper; OLI TIRS: Operational Land Imager Thermal Infrared Sensor; USGS: United States Geological Survey. 


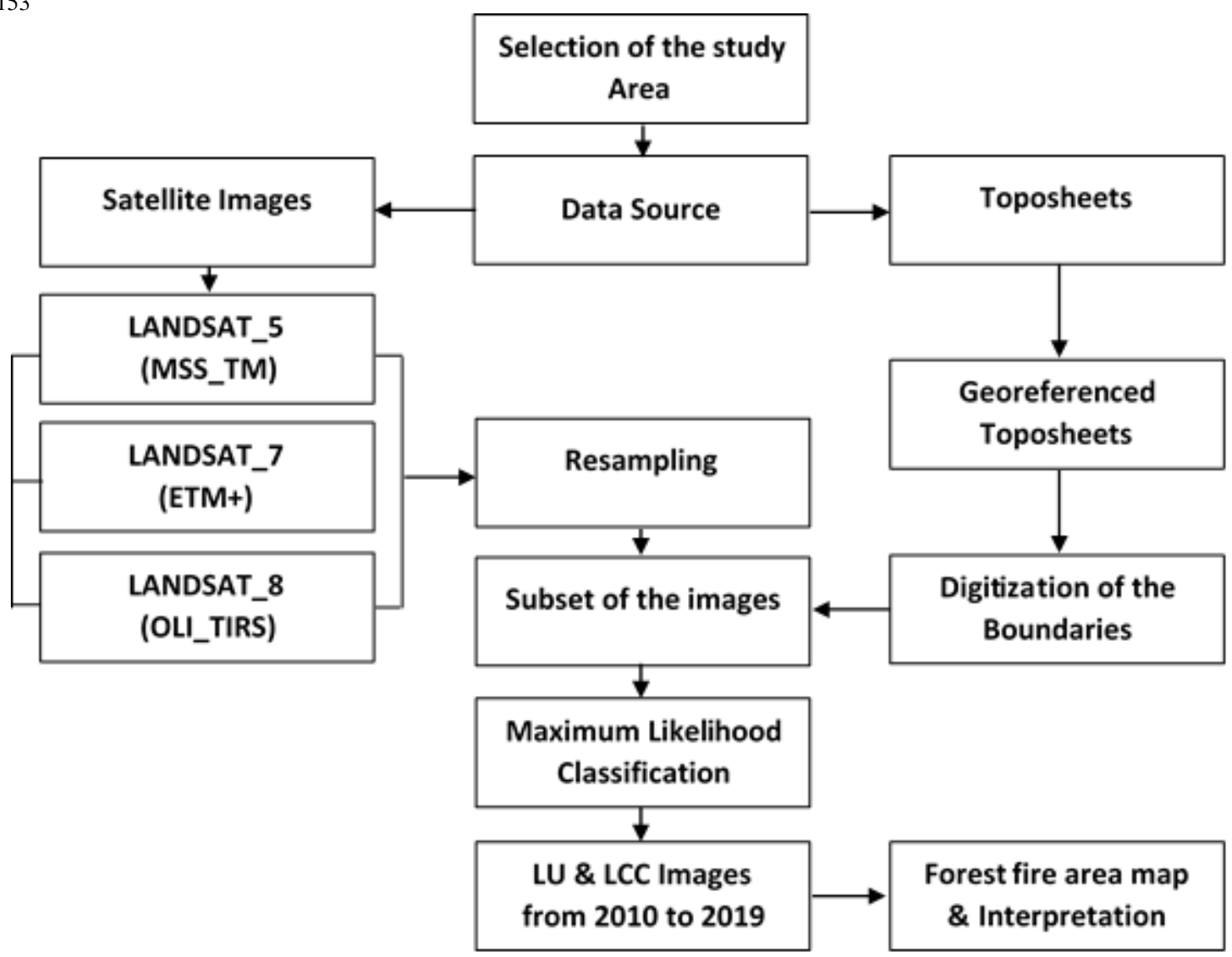

Figure 2. Flowchart of methodology for forest fire mapping.

\section{RESULTS AND DISCUSSION}

Forests of Karnataka which have their own savanna type of ecosystem comprises rich vegetation and wildlife. Sustained evolution and protection of these forests have made our forests rich in biodiversity. Bandipur Tiger Reserve is one among these forests. Causing fire in such savannah-type forests is a major threat to the flora and fauna, as well as the efforts to protect the endangered animal-bird habitats[12].

Bandipur Tiger Reserve covers an area of 913.04 square kilometers[4]. Satellite images have shown the vegetation type which is prone to fire during summer. At present it covers deciduous forests $(42.21 \%)$, shrub and grassland $(30.25 \%)$. In total, forest contains an area of $72.46 \%$ of the fire prone variety of plants and the remaining $27.54 \%$ of the area contains evergreen forest, Semi Evergreen Forest and Water Bodies. Refer the map of land use and land cover changes in the year 2019. Figure. 4

\section{A. Burnt area assessment}

In this study, fire prone areas have been identified with the help of Landsat Satellite Images and Geographical Information System (GIS) technology by looking into forest fires that broke out in numerous places across the Bandipur Tiger Reserve in every summer from 2010 to 2019 . Refer to figure 3.

There was an exception in the year 2018 because only a small area of $0.71 \mathrm{sq} \mathrm{km}$ was burnt but in the remaining nine years there were large forest fire events which burnt huge swaths of area. The year 2017 was noted with the highest fire spread in the forest ranges of Gundre, N. Begur, Ainar Marigudi, Maddur and Gopalaswamy Betta with a total area of 85.9 Sq kms. In the year 2019, there was an immense fire break out across the Gopalaswamy Betta, Moole Hole and Omkar ranges, with an area of $63.93 \mathrm{Sq} \mathrm{kms}$. This resulted in significant changes in vegetation. In 2012, forest fires were reported across an area of $40.73 \mathrm{Sq} \mathrm{kms}$ of forest in all eleven ranges. There were more fire breakouts in the Moliyar, Maddur and Gopalaswamy Betta ranges in 2014 compared to ranges like Omkar, Hediyala, Ainar Marigudi and N. Begur, with a total of $34.91 \mathrm{Sq} \mathrm{kms}$ of forest cover which turned into decline. And there is a distribution of forest fires blowing up in the Moliyar, Gundre, Hediyala, Omkar, Moole Hole and Gopalaswamy Betta Forest ranges in 2016, with 18.51 Sq kms of forest area. Refer Table.3 and Figure.3 According to some research, we can see a history of massive forest fire break out occurring in a very large area of $226 \mathrm{Sq} \mathrm{kms}$ in a single year in 2005 [9]. 

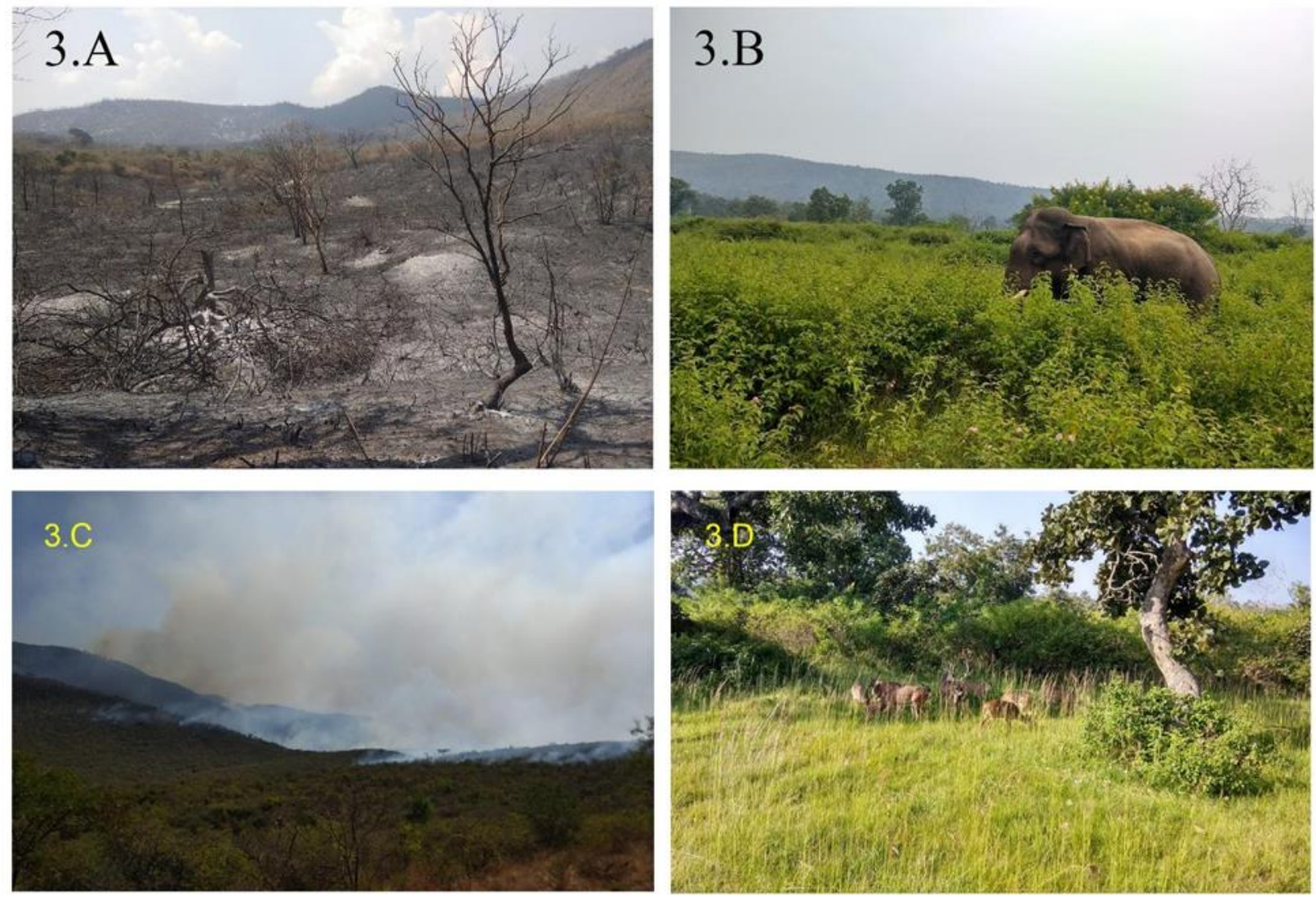

Figure 3.A) A scene from the 2019 forest fire in which large trees were caught in a fire.

3.B) Invasive plants such as Lantana spread rapidly in such areas.

3.C) The biggest forest fire in 2019 is in the Bandipur Tiger Reserve.

3.D) Persistent Forest fire in areas where Lantana is growing can cause grassland or shrub vegetation in such areas.

Table 3: The extent of forest fire damage in eleven ranges of Bandipur Tiger Reserve during 2010 to 2019.

\begin{tabular}{clrrrrrrrrrrr}
\hline & & \multicolumn{10}{c}{ Forest Fire Area $(\mathbf{k m 2})$} \\
\cline { 2 - 12 } Sl.No. & Forest Ranges & $\mathbf{2 0 1 0}$ & $\mathbf{2 0 1 1}$ & $\mathbf{2 0 1 2}$ & $\mathbf{2 0 1 3}$ & $\mathbf{2 0 1 4}$ & $\mathbf{2 0 1 5}$ & $\mathbf{2 0 1 6}$ & $\mathbf{2 0 1 7}$ & $\mathbf{2 0 1 8}$ & $\mathbf{2 0 1 9}$ & Total \\
\hline 1 & Gundre & 0 & 0.11 & 2.28 & 8.01 & 0 & 0.4 & 3.81 & 15.17 & 0 & 0 & $\mathbf{2 9 . 7 8}$ \\
2 & N.Begur & 0 & 0 & 0.36 & 0.07 & 0.4 & 2.22 & 0 & 23.17 & 0 & 0 & $\mathbf{2 6 . 2 2}$ \\
3 & Moliyar & 0 & 0.7 & 9.54 & 0.08 & 16.81 & 0 & 10.28 & 0 & 0.3 & 0 & $\mathbf{3 7 . 7 1}$ \\
4 & Ainar Marigudi & 0 & 0 & 3.93 & 0.07 & 1.99 & 0 & 0 & 32.61 & 0 & 0 & $\mathbf{3 8 . 6}$ \\
5 & Moole Hole & 1.51 & 2.13 & 13.56 & 0 & 0 & 1.27 & 0.33 & 0 & 0 & 6.3 & $\mathbf{2 5 . 1}$ \\
6 & Hediyala & 0.18 & 1.7 & 4.03 & 0 & 3.26 & 0 & 2.82 & 0 & 0 & 0 & $\mathbf{1 1 . 9 9}$ \\
7 & Omkar & 0.51 & 2.77 & 4.39 & 0 & 1.41 & 0 & 1.07 & 0 & 0 & 1.23 & $\mathbf{1 1 . 3 8}$ \\
8 & Maddur & 0.96 & 0.48 & 1.38 & 0 & 5.06 & 0 & 0 & 9.71 & 0 & 0.14 & $\mathbf{1 7 . 7 3}$ \\
9 & Gopalaswamy Betta & 1.47 & 0.25 & 0.85 & 0 & 0.31 & 0.13 & 0 & 5.24 & 0 & 54.82 & $\mathbf{6 3 . 0 7}$ \\
10 & Bandipur & 0.91 & 1.82 & 0.3 & 0 & 5.67 & 0.2 & 0.2 & 0 & 0.41 & 0.69 & $\mathbf{1 0 . 2}$ \\
11 & Kundakere (Moyar) & 0 & 0.81 & 0.11 & 0 & 0 & 0 & 0 & 0 & 0 & 0.75 & $\mathbf{1 . 6 7}$ \\
\hline & Total & $\mathbf{5 . 5 4}$ & $\mathbf{1 0 . 7 7}$ & $\mathbf{4 0 . 7 3}$ & $\mathbf{8 . 2 3}$ & $\mathbf{3 4 . 9 1}$ & $\mathbf{4 . 2 2}$ & $\mathbf{1 8 . 5 1}$ & $\mathbf{8 5 . 9}$ & $\mathbf{0 . 7 1}$ & $\mathbf{6 3 . 9 3}$ & $\mathbf{2 7 3 . 4 5}$ \\
\hline
\end{tabular}



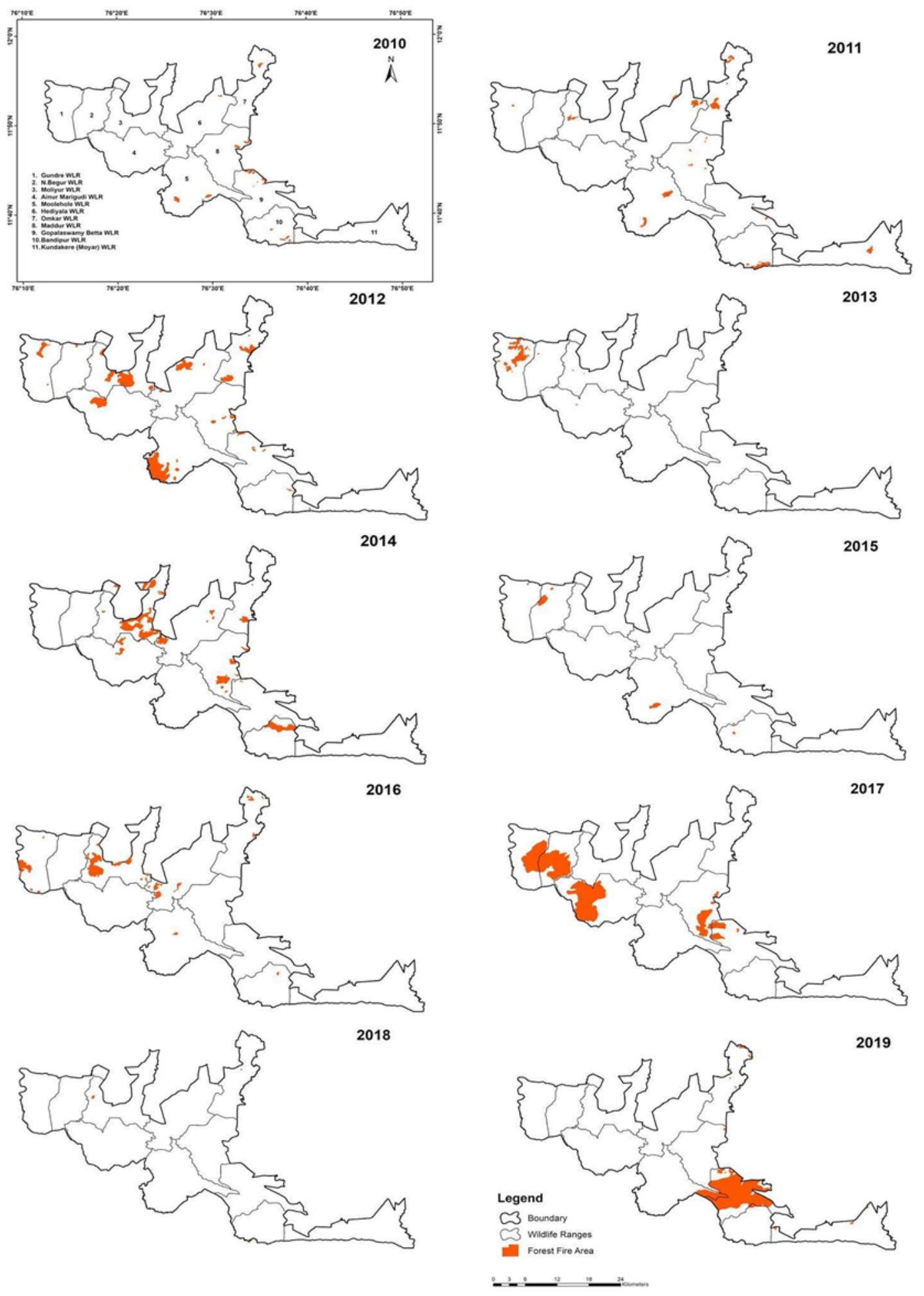

Figure 3. The extent of forest fire areas for the years from 2010 to 2019 
ISSN 2250-3153

Considering these statistics, we can observe that forest fires have been consistent from 2010 to 2019 (Table 4) during the summer season. From the observation period of ten years, forest fires have occurred for 3 and 4 years in Kundakere (Moyar) and Ainar Marigudi respectively and have occurred for 5 consecutive years in the N.Begur and Hediyala ranges. Forest fires have occurred in Gundre, Moliyar, Moole Hole, Omkar and Maddur ranges for 6 years in a row. The most severe forest fire occurred in Gopalaswamy Betta and Bandipur ranges for 7 and 8 years respectively (Table 4). Maximum change in forest vegetation can be seen if there are repeating forest fires. The result of these persistent forest fires is that the area is subjected to aridity and subsequently converted into shrubs or grasslands[13]. We can see this scenario in Bandipur Tiger Reserve in the face of this research.

Table 4: Total years of forest fire during the study period from 2010 to 2019.

\begin{tabular}{clc}
\hline Sl.No. & \multicolumn{1}{c}{ Forest Ranges } & Total years of forest fire \\
\hline 1 & Gundre & 6 \\
2 & N.Begur & 5 \\
3 & Moliyar & 6 \\
4 & Ainar Marigudi & \multicolumn{2}{|c}{} \\
5 & Moole Hole & 6 \\
6 & Hediyala & \multicolumn{2}{|c}{5} \\
7 & Omkar & 6 \\
8 & Maddur & 6 \\
9 & Gopalaswamy Betta & \multicolumn{2}{|c}{7} \\
10 & Bandipur & 8 \\
11 & Kundakere (Moyar) & 3 \\
\hline
\end{tabular}

\section{B. Land Use and Land Cover Change}

Vegetation plays a major role to identify fire prone areas in the forest. For that, vegetation maps of forests are required. Landsat satellite data was used for mapping based on Land Use and Land Cover Changes. Land-Use and Land-Cover maps are prepared by observing different types of vegetation like Evergreen Forest, Semi Evergreen Forest, Deciduous Forest, Scrub / grasslands and water bodies. In 2010, Evergreen Forest had forest cover of $73.15 \mathrm{sq} \mathrm{km} \mathrm{(8.01 \% )} \mathrm{which} \mathrm{shrunk} \mathrm{to} 63.19 \mathrm{sq} \mathrm{km}(6.92 \%)$ by 2019 i.e., $9.96 \mathrm{sq}$ $\mathrm{km}(1.09 \%)$ of the evergreen forest. Semi Evergreen Forest had the forest cover of $175.98 \mathrm{sq} \mathrm{km} \mathrm{(19.27 \% )} \mathrm{in} 2010$ and by 2019 it had expanded to $185.94 \mathrm{sq} \mathrm{kms}(20.36 \%)$ i.e., $9.95 \mathrm{sq} \mathrm{kms} \mathrm{(1.09 \% )} \mathrm{of} \mathrm{semi} \mathrm{evergreen} \mathrm{forest} \mathrm{had} \mathrm{increased.} \mathrm{In} \mathrm{this} \mathrm{research,} \mathrm{we} \mathrm{observed}$ 10 years of Satellite images, which clearly shows that forest fires occur consistently every summer in the evergreen forests, resulting in about $1 \%$ of evergreen forests being converted to semi-evergreen forests.

In 2010, the Deciduous Forest had forest cover of $407.38 \mathrm{sq} \mathrm{kms} \mathrm{(44.61 \% )} \mathrm{which} \mathrm{decreased} \mathrm{to} 385.44 \mathrm{sq} \mathrm{kms} \mathrm{(42.21 \% )} \mathrm{by} 2019$, which yields to $21.93 \mathrm{sq} \mathrm{kms} \mathrm{(2.40 \% )} \mathrm{of} \mathrm{forest} \mathrm{loss.} \mathrm{The} \mathrm{Shrub} \mathrm{/} \mathrm{Grassland} \mathrm{type} \mathrm{of} \mathrm{vegetation} \mathrm{was} 255.69 \mathrm{sq} \mathrm{kms}(28 \%)$ in 2010 . By 2019 , it increased to $276.20 \mathrm{sq} \mathrm{kms}(30.25 \%)$ an increment of $20.51 \mathrm{sq} \mathrm{kms} \mathrm{(2.24 \% ).} \mathrm{Similarly,} \mathrm{if} \mathrm{we} \mathrm{observe} \mathrm{satellite} \mathrm{images} \mathrm{there}$ are continuous forest fires every summer in the deciduous forest, resulting in about $20 \mathrm{sq} \mathrm{kms}(2 \%)$ metamorphosing into dry deciduous forests, shrubs or grasslands. Refer Table 5.

Table 5. Area coverage of Bandipur Tiger Reserve land use \& land cover change categories in 2010 \& 2019

\begin{tabular}{|c|c|c|c|c|c|c|c|}
\hline \multirow[t]{2}{*}{ Sl.No. } & \multirow[t]{2}{*}{ Classified } & \multirow{2}{*}{$\begin{array}{c}2010 \\
\text { Area }(\mathrm{Sq} . \mathrm{km}) \\
\end{array}$} & \multicolumn{3}{|c|}{2019} & \multicolumn{2}{|c|}{ Changes } \\
\hline & & & $\%$ & Area (Sq. km) & $\%$ & Area (Sq. km) & $\%$ \\
\hline 1 & Evergreen Forest & 73.1565 & 8.0122 & 63.1881 & 6.9205 & -9.9684 & -1.0917 \\
\hline 2 & Semi-Evergreen Forest & 175.9869 & 19.2745 & 185.9382 & 20.3644 & 9.9513 & 1.0899 \\
\hline 3 & Deciduous Forest & 407.3823 & 44.6176 & 385.4466 & 42.2151 & -21.9357 & -2.4025 \\
\hline 4 & Shrub/Grassland & 255.694 & 28.0042 & 276.2037 & 30.2505 & 20.5097 & 2.2463 \\
\hline \multirow[t]{2}{*}{5} & Water Bodies & 0.833 & 0.0912 & 2.2761 & 0.2492 & 1.4431 & 0.158 \\
\hline & Total & 913.0527 & 100 & 913.0527 & 100 & & \\
\hline
\end{tabular}

This publication is licensed under Creative Commons Attribution CC BY. 

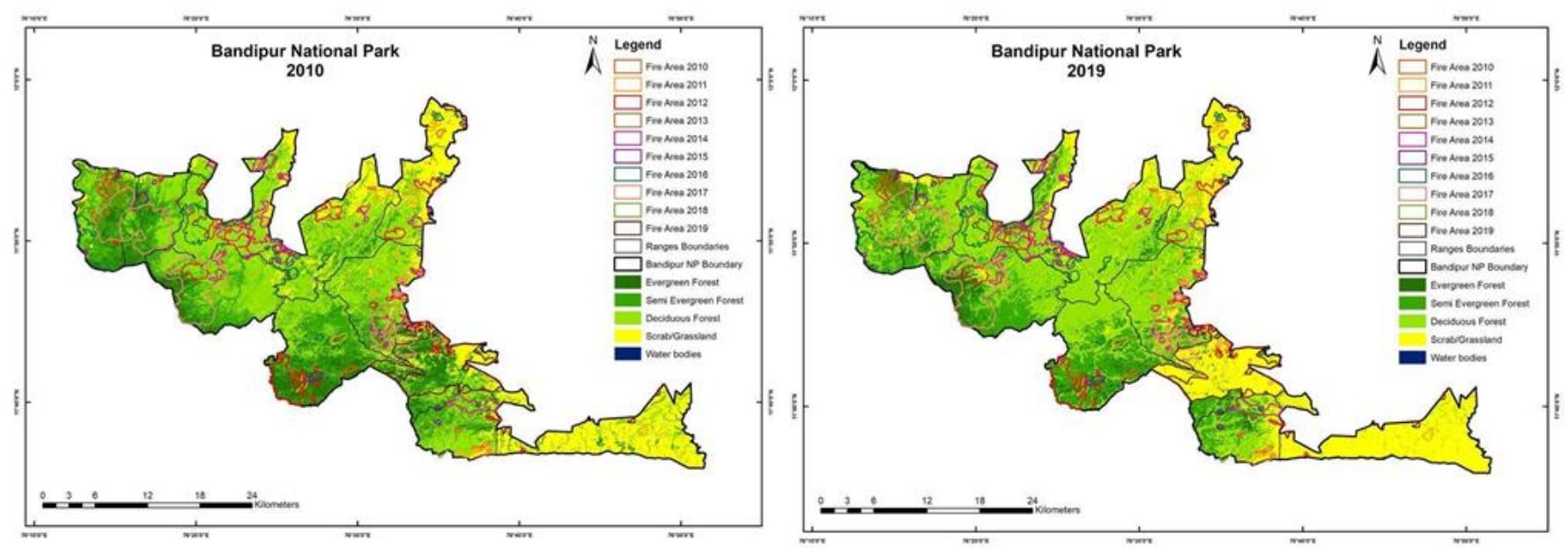

\section{Figure 4: Land Use and Land Cover Classification of Bandipur Tiger Reserve in 2010 and 2019 with details of forest fire spread from 2010 to 2019.}

\section{Illustration based on wildlife ranges of Bandipur Tiger Reserve}

The study shows that from 2010 to 2019, the Gopalaswamy Betta, Bandipur, Maddur, Kundakere (Moyar) and Omkar ranges have decreased by $45.55 \mathrm{sq} \mathrm{kms}$ of evergreen vegetation. This means that it has changed to a semi-evergreen pattern of vegetation. It has been noticed that there is a decrease in Semi-Evergreen pattern vegetation by $25.65 \mathrm{sq} \mathrm{kms}$ in Gundre, N. Begur, Ainar Marigudi, Moole Hole, and Hediyala ranges. This infers that the vegetation of the Semi-Evergreen has been replaced by the Deciduous.

The grassland area has been increased in the area of Gopalaswamy Betta, Hediyala, Kundakere (Moyar), Moliyar and N.Begur of about 53.49 sq kms. Deciduous forest type of vegetation has been increased in the Moole Hole, Omkar, Maddur, Bandipur and Kundakere (Moyar) ranges by about 33 sq kms. In areas where forest fires have burst out, shrubs and grasslands have increased significantly. Considering the overall statistics or map of land use and land cover changes, it can be seen in this study that the effect of persistent forest fire has changed evergreen, semi-evergreen into dry deciduous forest, shrubs and grasslands.

\section{CONCLUSION}

We will be fools in a wise disguise if we don't act and react to conserve and preserve the existing natural habitats of whatever type. According to the Karnataka State Natural Disaster Monitoring Center (KSNDMC), the recent heat wave has created drought in some taluks of Mysore and Chamarajanagar districts surrounding the Bandipur Tiger Reserve and temperature has soared to $40^{\circ} \mathrm{C}$ [14-15]. According to research, forest fires are accountable for an increase of $20 \%$ in global warming[16].

In recent years, forest fires have become common as a result of anthropogenic activity. Fire engulfs all life forms charring whatever comes in its way mercilessly. From over a decade of study, $1.09 \%$ of evergreen forests have declined, $1.09 \%$ of semi-evergreen forests have increased. i.e., due to the forest fire effect about $1.09 \%$ of evergreen forests have become semi-evergreen. The dry deciduous forest area of $2.40 \%$ has reduced and $2.24 \%$ were replaced by shrub or grassland vegetation. If forest fires occur in the same area every year, they become a haven for weeds like lantana. Such a situation can be seen in the study of Bandipur Tiger Reserve. The forest department, on the other hand, has continued to develop grassland on 3000 acres of the Bandipur Tiger Reserve, despite the steady rise in the amount of grassland. There is no need to develop artificial pastures[17]. Study finds that grasslands are developing naturally.

\section{A. Suggestions}

1. The change in vegetation from forest fires can greatly affect the diet and habitat of wildlife. To control this, we must focus on scientific practices rather than traditional ones.

2. Modern technologies like Remote Sensing technology and satellite imagery should be adopted by the forest department.

3. There is a need for new scientific research on forest fire and its control. 


\section{ACKNOWLEDGMENT}

I am thankful to the Mahadeva K.C. who worked along with me during the fieldwork for the above article. I am thankful to Murali S., Vipin Baliga and Shanthamma S. for providing advice and suggestions. And I am also grateful to the University of Bangalore and Wildlife Conservation Group for providing financial aid.

\section{REFERENCES}

[1] A. J. T. Johnsingh, R. Raghunath, R. Pillay, and M. D. Madhusudan, "Ensuring the future of the tiger and other large mammals in the southern portion of the Nilgiri Biosphere Reserve, southern India," J. Bombay Nat. Hist. Soc., vol. 107, no. 2, pp. 77-85, 2010.

[2] R. Vishwanath, "Peak hidden in a veil of mist," Deccan Herald, Bangalore.

[3] Karnataka Forest Department, "Bandipur Tiger Reserve," Forest Department of Karnataka, 2019. https://aranya.gov.in/aranyacms/(S(utzob12tdmde0ec1kuchtzi3))/English/TigerReserves.aspx.

[4] S. N. S. Rajappa, "Bandipur Tiger Reserve Division," Forest Department of Karnataka, 2019. https://aranya.gov.in/aranyacms/(S(1c2niogi2evoufs0etx11o2n))/English/FieldDivision.aspx?u15HOwzBSyvjqM6114DzSA==.

[5] D. K. Ashutosh and Satendra, FOREST FIRE DISASTER MANAGAMENT National Institute of Disaster Management. 2014.

[6] M. J. Z. Jan L. Beyers, James K. Brown, Matt D. Busse, Leonard F. DeBano, William J. Elliot, Peter F. Ffolliott, Gerald R. Jacoby, Jennifer D. Knoepp, Johanna D. Landsberg, Daniel G. Neary, James R. Reardon, John N. Rinne, Peter R. Robichaud, Kevin C. Ryan, Arthur, "Effects of Fire on Soil and Water," Catena, vol. 9, no. 2, pp. 1-5, 2005, doi: 10.1016/j.catena.2008.03.011.

[7] F. K. Dwomoh and M. C. Wimberly, "Fire regimes and forest resilience: alternative vegetation states in the West African tropics," Landsc. Ecol., vol. 32, no. 9, pp. 1849-1865, 2017, doi: 10.1007/s10980-017-0553-4.

[8] M. of E. and Forest, "Bandipur National Park ESZ,” New Delhi, 2012. [Online]. Available: https://www.aranya.gov.in/downloads/Bandipur National Park ESZ.pdf.

[9] R. K. Somashekar, P. Ravikumar, C. N. Mohan Kumar, K. L. Prakash, and B. C. Nagaraja, "Burnt area mapping of Bandipur National Park, India using IRS 1C/1D LISS III data," J. Indian Soc. Remote Sens., vol. 37, no. 1, pp. 37-50, 2009, doi: 10.1007/s12524-009-0010-1.

[10] K. N. Ashwatha, "A Geographical Analysis of Challakere Amrit Mahal Kaval Grasslands. Using Remote Sensing and GIS Technologies,” J. Geogr. Environ. Earth Sci. Int., vol. 24, no. 7, pp. 56-71, 2020, doi: 10.9734/jgeesi/2020/v24i730243.

[11] G. N. Vivekananda, R. Swathi, and A. V. L. N. Sujith, "Multi-temporal image analysis for LULC classification and change detection," Eur. J. Remote Sens., vol. 00, no. 00, pp. 1-11, 2020, doi: 10.1080/22797254.2020.1771215.

[12] K. S. Vinayaka and Y. L. Krishnamurthy, "Floristic composition and vegetation analysis of Hulikal Ghat region, central Western Ghats, Karnataka," Trop. Plant Res., vol. 3, no. 3, pp. 654-661, 2016, doi: 10.22271/tpr.2016.v3.i3.086.

[13] J. D. Coop et al., "Wildfire-Driven Forest Conversion in Western North American Landscapes," Bioscience, vol. 70, no. 8, pp. 659-673, 2020, doi: 10.1093/biosci/biaa061.

[14] Bhavana S, "KSNDMC warns of heatwave in four Karnataka district, asks people not to go out," News Karnataka, Bangalore, May 2020.

[15] SHILPA P, "Drought hits 70 taluks hard in Karnataka," Deccan Chronicle, Bangalore, Aug. 2016.

[16] Navin Singh Khadka, "Climate change: Worries over CO2 emissions from intensifying wildfires," BBC NEWS, Environment correspondent, BBC World Service, California, Nov. 2018.

[17] R. Krishna Kumar, "Seed-sowing completed in Bandipur to reclaim grassland," The Hindu, Mysore, Aug. 2019.

\section{AUTHORS}

First Author - Ashwatha K.N., (PhD Research Scholar), Dept. of Geography \& Geoinformatics, Bangalore University, Bengaluru - 560056 Karnataka, INDIA., kn.ashwatha@gmail.com

Second Author - Tejaswini J. S., BE in Information Science and Technology, Wildlife Conservation Group, Adavi Field Station, Ragihalli Post, Bengaluru - 560083, Karnataka, INDIA., teju06.pinky@gmail.com

Third Author - Dr. A. S. Rayamane, Professor, Dept. of Geography \& Geoinformatics, Bangalore University, Bengaluru - 560056 Karnataka, INDIA., profasrayamane@yahoo.com

Correspondence Author - Ashwatha K.N., kn.ashwatha@gmail.com , teju06.pinky@gmail.com 